I Universidade de Brasília (UnB), Departamento de Sociologia,

Brasília, DF, Brasil

sergiotavolaro@hotmail.com

https://orcid.org/oooo-0003-2755-336I

Sergio B. F. Tavolaro'

\title{
STASIS, MOTION AND ACCELERATION: THE SENSES AND CONNOTATIONS OF TIME IN RAÍZES DO BRASIL AND SOBRADOS E MUCAMBOS (1936) ${ }^{1}$
}

It will perhaps appear somewhat redundant to highlight the prominent place held by Sérgio Buarque de Holanda and Gilberto Freyre, as well as the relevance of Raízes do Brasil (Roots of Brazil: hereafter Roots) and Sobrados e mucambos (The mansions and the shanties: hereafter Mansions), among the ample and diverse list of authors and works to have shaped "Brazilian thought." In this article, I reprise the interest in these interpreters and their essays, but with a somewhat restricted purpose in mind: I wish to revisit the senses and connotations of the category "time" that work to define the cognitive horizons and ground the formulations contained in the first editions of the works exploring Brazilian social experience. ${ }^{2}$ It should be immediately stressed that the disagreements between Freyre and Holanda and between their respective works were not few in number, as amply highlighted by the critical literature. This said, the article's emphasis pursues another direction: in dialogue with this same literature, I propose to examine the affinities and points of convergence between Roots and Mansions concerning this specific problematic. In fact, while we can affirm, as Elide Bastos (2013: 288) proposes, that "the main line of inquiry present in the various moments of development of Brazilian social thought concerns the question of delay, ${ }^{3}$ " it seems to me equally plausible to surmise that the most renowned essays interpreting Brazil tend to allude to a temporal configuration in the country distinct from the kind commonly attributed to "paradigmatic" modern societies. ${ }^{4}$ As I aim to show, these same anxieties pervade many of the 
questions and aspects contemplated in Mansions and Roots as part of their attempts to elucidate the geneses of Brazilian society and analyse the impacts of the transformations that shook the country from the nineteenth century on. Just as important, I also wish to explore their potential contributions to a particular area of reflection in contemporary social theory: my aim is to probe the contributions these essays can make to expanding the sociological repertoire on social experience under modernity.

Some methodological explanations are necessary. The first concerns the selection of these essays rather than other works by the same interpreters: aside from their prominence in Brazilian thought, the choice derives from the fact that these are the works in which Sérgio Buarque and Freyre focused more systematically and exhaustively on the modernization of Brazilian society in articulation with the country's formation processes. In this sense, more so than others from their output, these two works offer an unparalleled opportunity to investigate the problems delineated here. The second explanation relates to the choice of the first editions of Mansions and Roots: both the essays gained new versions after 1936 and, moreover, the later editions underwent innumerable alterations, some of them patent in their interpretative implications. While acknowledging the relevance of the aspects later incorporated into the inaugural texts, my preference for the first editions derives from my interest in investigating the original contributions of Roots and Mansions to the intellectual landscape of the first decades of the twentieth century. I should also observe that, although a promising line of inquiry, it is beyond the scope of the article to explore the significances that such modifications may have for the questions discussed here, just as it is not my goal to compare the content of the inaugural publications of Mansions and Roots with other works by Freyre and Holanda that either precede or follow them. Finally, I should also emphasize that it lies outside my present remit to explore the possible impacts of the intellectual sources and references of these authors on the ideas found in Mansions and Roots concerning the problematic of time in Brazil. Each of these other concerns would require a specific work.

In fact, the idea is not alien to the critical literature that, like other interpreters, Sérgio Buarque and Gilberto Freyre detected a composite temporal configuration in Brazilian society, appreciably different from the kind of configuration most often identified in contexts taken as originary and/or in the avant-garde of modern experience (eo ipso "prototypical"): in other words, Brazil displayed a configuration that diverged from the latter's abstract, uniform, progressive and linear connotation of time (Bastos, 2003: 78; Feldman, 2009: I 4 ; Lage, 20I6: 354-355; Nicodemo, 20I4: 54; Pesavento, 2005: I7-79; Vecchi, 2005: I70; Villas Bôas, 2003: I 20-I2I). My interest focuses on the fact that this presumed disparity is very frequently linked to the country's supposed divergences from other parameters (political, institutional, economic, social, cul- 
tural, ethical-moral, epistemological and aesthetic) also discerned in so-called central countries. Ultimately, the argument goes, we are left with two substantively different modalities of societal experience, constructed over the course of unmistakably diverse historical trajectories. Still in the early stages of my research, however, this framing seemed far from exhausting the full heuristic potential of Roots and Mansions. From early on, I felt that the senses of time that support their depictions of Brazil might refer to something more than the country's paths and its (alleged) deviations. Undoubtedly, the critical literature on the two authors has itself glimpsed in their reflections a critical tone in relation to the imaginary of modernity (Avelino Filho, I990; Bastos, 2003; Burke \& Pallares-Burke, 2009; Cavalcante, 2008; Crespo, 2003; Larreta \& Giucci, 2007; Motta, 2013; Vecchi, 2005; Villas Bôas, 2003). Nonetheless, the bibliography shows a general tendency to take these works, along with others by Holanda and Freyre, as works whose cognitive potential is mostly limited to "non-model" contexts - that is, societies that supposedly entered modernity in a delayed and/or marginal fashion because of special circumstances.

The article sets out to explore an alternative interpretation: my hypothesis is that, while they indeed strove to explain an experience that seemed to them "anti-paradigmatic" in various aspects, Mansions and Roots succeed in providing valuable clues to a critical appreciation of a certain "substantialist" 5 and "internalist" bias ${ }^{6}$ underlying the imaginary of modernity and its temporality(ies). As I wish to argue in this article, performing this exercise requires accentuating and amplifying the implications of the transactional/relational dimension of the works: I refer to a certain dimension of their propositions that fixes the geneses of Brazilian society and its modernization in the country's multiple social entanglements, connections and exchanges (Rocha, 2008; Feldman, 2009; Lage, 2016). Also according to my hypothesis, seen from this perspective, Roots and Mansions encourage us to explore the pattern of sociability and the senses of time most frequently attributed to Brazilian experience not merely as manifestations and developments of its "singular," "delayed" and/or "peripheral" condition within the modern context - as I observed, an appraisal recurrent in the critical literature. Instead, this alternative perspective would enable us to conceive at least some of the traces and aspects discerned in this pattern and this temporal configuration as facets of modernity itself, generally obfuscated by the sociological imagination or, in the best case scenario, closely associated with so-called "non-model experiences". In this case, the works in question can be affirmed to possess elements that assist the sociological imaginary to amplify and diversify the array of notions and concepts used to codify, describe and comprehend modernity.

A final preliminary observation. Although neither Mansions or Roots actually formalize or systemize a sociological theory concerning time, this does not justify limiting our discussion of them to empirical questions. In considering 
the content of their reflections, it seems to me both legitimate and promising to interrogate the propositions of the essays with theoretical questions too, exploring their articulations and potential contributions to the sociological imagination.

\section{THREE MEANINGS OF TIME IN ROOTS AND MANSIONS}

According to Pedro Monteiro's (2015: 77) analysis, in addition to their stylistic differences, Roots and Mansions are founded on clearly disparate principles: while Sérgio Buarque's essay "is constructed under the sign of conflict," Mansions is written "under the sign of reconciliation, balance and adaptation". Indeed, any analysis that sets out to compare them is compelled to admit that they comprise works and authors in various aspects unmistakable. To begin with, though from the same generation, Freyre and Holanda not only lived and acted in different regions of the country involved in distinct intellectual disputes, they also pursued their own personal, professional and institutional trajectories (Burke \& Pallares-Burke, 2009: 35-76; Candido, 2008: 29-3I; Monteiro, 20I5: 58; Rocha, 20I 2: 37). No less important, their works reflect different analytic starting points, as well as expressing sometimes incompatible methodological and interpretative perspectives, informed, in turn, by theoretical-intellectual references with their own well-known specificities (Bastos, 2008: 227-228; Feldman, 2009: 85; Monteiro, 20I5: 56-57; Motta, 2013: 224; Nicodemo, 20I4: 52-53; Burke, 20I3: 208; Crespo, 2003; Mata, 20I6: 66-69; Rocha, 2008: 249, 264; Waizbort, 20II). This divergent background combines with diverse thematic interests, as well as a preference for distinct explanatory frameworks (Araújo, I994; Bastos, 2006; Ferreira, I996: 232-242; Monteiro, 20I5: 59; Souza, 2000: I6II67, 205-270). Ultimately, there is no shortage of elements to confirm these discrepancies, equally expressed in dissonant diagnoses and judgments about the country's present attributes and future potential - not infrequently translated into politico-ideological positions that grew deeper with the passing of the years (Candido, 2008: 29-36; Eugênio, 2008: 45I-452; Melo, 2016: 454-455; Monteiro, 20I5: 7 I-74; Nicodemo, 20I4: 47-49; Rocha, 20I 2: 36; Souza, 2000: 2 I I 2I2; Waizbort, 20I6: 469-470). Attentive to these differences, the article proposes a different exercise: focused on the specific objective of analysing the problematic of time and its senses in Mansions and Roots, as well as their contributions to the sociological imagination, I wish to explore the confluences and affinities of the two works.

On the very first pages of Roots of Brazil, Sérgio Buarque alludes to "forms of life" and "institutions", as well as to a certain "worldview" [visão do mundo] (Holanda, 1936: 3), ${ }^{8}$ inherited by Brazilians through "an Iberian nation," belonging to a "border, transition zone" [zona fronteiriça, de transição] that would over time become a bridge of communication between Europe and "other worlds" (Holanda, I936: 4). The close attention paid to this past scenario was justified 
by the enormous implications that Portugal and Spain's "delayed entry" [ingresso tardio] into the "European chorus" [côro europeu] - consummated only "from the era of the discovery of America" - had "for their destinies, determining many aspects of their history and spiritual formation" (Holanda, I936: 4). Mutatis mutandis, something similar occurs in the evaluations of The mansions and the shanties: Freyre is also occupied with the primordial origins of Brazilian society, in his view clearly distinct from the inaugural moments of the paradigmatic contexts of modernity, emphasizing its "three centuries of relative segregation from non-Iberian Europe" (Freyre, I936: 257), during which the country had seen the delineation of "a social landscape with many Asiatic, Moorish and African elements" [uma paizagem social com muita coisa de asiatico, de mourisco, de africano] (Freyre, I936: 258).

The size of the explanatory burden consigned to the antecedents and primordial origins of contemporary Brazil did not pass unnoticed by the critical literature, attentive to its supposedly persistent past, relatively impervious to change, the source of world conceptions, mental configurations, aesthetic references, ways of life, behaviours, values and institutions taken as very different to the forms and patterns of modern societies (Bastos, 2008: 227-229; Cavalcante, 2008: I50-I5I; Feldman, 2009; Ferreira, I996: 235; Nicodemo, 20I4: 58; Souza, 2000: I6I-I67; Wegner, 2000: 29, 33, 39, 5I). These aspects are said to explain many of Brazil's inner descompassos, desencontros, desajustes and desacertos (divergences, discrepancies, mismatches and maladjustments), as well as its decalagens (dealignments) vis-à-vis the prototypical modern scenarios (Avelino Filho, I990: 7-8; Bastos, 2003: I35; 2008: 228; Cavalcante, 2008: I50-I5I; Feldman, 20I3: I33-I34; Ferreira, I996: 244; Melo, 2016: 45I; Pesavento, 2005: 65-69; Vecchi, 2005: I7I; Waizbort, 20I I: 48-49, 50; Wegner, 2000: 49-50).

Whatever the case, while recognizing the relevance and influence attributed to the past, the incursion made by Roots and Mansions in the most remote origins of Brazil far from exhausts the ways in which the essays allude and refer to time. The critical literature itself highlights the semantic excesses surrounding this aspect: according to Roberto Vecchi (2005: 168), Roots evokes both "a regressive time and another progressive time [that] forge the contemporaneity" of the country, or indeed a temporal configuration characterized by the "complex and indivisible combination of present and past, in the folding of the past into the present" (Vecchi, 2005: I65). Sandra Pesavento (2005: 64, original emphasis), for her part, argues that Sérgio Buarque "works with multiple temporalities [...]: that of permanencies or the long term [...] and that of changes or the short term [...], in addition to the cosmic triad constructed by men over the course of history (a present, a past, a future)." In the case of Freyre, Elide Bastos draws our attention to the influence of Ortega y Gasset's notion of a tempo tríbio in the "sociological dimension" of his reflections, expressed in his non-linear perception of the transformations experienced by the country, and 
in the idea of an overlapping and a "simultaneity of the times of formation, consolidation and decline" (Bastos, 2003, p. 83-84), or even a "simultaneity of present, past and future times" (Bastos, 2003: 95, original emphasis). Along the same lines, Luiz Feldman (2009) and Victor Lage (20I6) converge in pointing out, respectively, the "temporal complementarity between past and present" (Feldman, 2009: 69-70) inscribed in Casa-grande \& senzala (published in English as The masters and the slaves) and Mansions, as well as the author's "general concern" with "the interpretation of the past, in order to understand the present and the future of Brazil" (Lage, 20I6: I26). Aware of these proposals, and given the specific concerns of the present article, I wish to adopt a slightly different terminology: in my view, coexisting with a static acceptation of time, the depictions and diagnoses of the country delineated in Mansions and Roots are also based on images of a time in motion, referring to a society whose identity slowly took shape over the course of formative processes and movements; finally, time appears in these essays as an index and agent of sudden dizzying transformations that, impacting on Brazil's ways of life, behavioural references, institutions and values, impelled the country towards modern societal forms and their corresponding cognitive, practical-moral and aesthetic-expressive patterns - that is, as suggested by Pesavento $(2005: 65,70,72)$, a time that accelerated under the pace of modernity. ${ }^{9}$

\section{STASIS: RETICENCES OF THE PAST}

Writing about Brazil's connections "to the Iberian Peninsula, and Portugal especially" and while recognizing the unique aspects forged through the colonizing adventure in America, Sérgio Buarque nonetheless symptomatically concludes that "a long and living, very much living tradition" [uma tradição longa $e$ viva, bastante viva] continues to feed "a common soul even today" (Holanda, I936: I5). In reality, the content of this proposition, alluding to the paradox of a time that does not flow, a stagnant/inert temporality, indicates a recurrent feature of the essays examined here: both works refer, with enormous frequency, to habits, behavioural patterns, norms, values, feelings, ways of thinking, institutions and even extra-social aspects (psychic, organic and environmental) out of tune with modern forms in order to assert that, although tracing back to a remote past, they remain very much alive in the present, to the point not only of attenuating "Brazil's re-Europeanization" [re-europeisação do Brasil] but also of "conserving as far as possible in the country the anti-European traits and colours, enlivened [avivadas] by deep centuries of segregation" (Freyre, I936: 259). Notably both Roots and Mansions emphasize the innumerable future implications of these reticences of the past - the case, for example, of the longterm effects of the centrality of the patriarchal family during the colonial period, where, according to Holanda, it is possible to comprehend "the retrograde spirit [espirito retrogrado] that dominated the organization of our public ser- 
vices," imposing an "important resistance" to the "large-scale undertakings" [grandes emprehendimentos] and transformations working to push Brazil in other directions (Holanda, I936: 46). Mansions has the very same impetus, asserting that: "Patriarchal or semi-patriarchal privatism still dominates us" (Freyre, I936: 23, original emphasis). This is why, despite being dazed by the new airs and confronted with new and very different behavioural models, forms of sociability mostly linked to tradition had resisted being supplanted or completely disfigured by societal codes of another kind. Of course, we should not underestimate the sensitivity of Roots and Mansions to the transformations that, attesting to the passage of time, eventually altered the physiognomy of Brazilian society. Nonetheless, neither can we ignore the insistent referrals in these works to aspects that, although rooted in the past - whether as direct products of Brazil's long-term cultural heritage (both European and extra-European) or even as habits, practices, institutions and ways of perceiving reality forged in original form in the Americas - appeared to Freyre and Holanda to persevere, projecting themselves into Brazil's present and, in this way, hindering the course of time.

\section{MOTION: MOVEMENT AND FORMATION}

Though fundamental, the inertial dimension of time - most often associated with the past and tradition - does not, of course, close off the perceptual horizons of Mansions and Roots. These are essays expressly concerned with discussing the effects of changes that, intensified and accelerating from the nineteenth century, worked to alter the features of Brazilian society in decisive fashion. But neither does this preoccupation exhaust all the analytic ambition of the works, keen to search for the supposedly more fundamental traits of Brazil. In this case, while they focus on the diverse legacies responsible for limiting in advance the range of possibilities available to the colonial adventure, Roots and Mansions also revisit the processes, syntheses and injunctions that, even before the country's modernization, had already contributed to building this "experience without simile" [experiencia sem simile] (Holanda, I936: 3). This new analytical angle pursued by the two works exposes a second sense of the category "time", in turn indicative of the initial processes of the country's formation - a time in movement.

We should immediately highlight the care taken by the two essays to explore the "internal" motives for the transformations that began to awaken the colonial experience from its centuries-long stupor. As is well-known, the author of Roots even comes to suspect Brazil's real capacity to "create spontaneously" (Holanda, I936: 7). Nonetheless, concurring about its very often sporadic and incipient nature, while pondering what had occurred on the "Piratininga plateau" [planalto de Piratininga] in remote times, Sérgio Buarque identifies an intrinsic dynamism within the new land, signalling "a new moment of our national history" (Holanda, I936: 72) - the germ of "a new sense of time" (Pesavento, 2005: 60): there, the disentanglement of colonial life from "its roots on the other side of the ocean" - its separation from 
the "stimulus of the metropolis" - was foreshadowed (Holanda, I936: 72). These transformative impulses, expressions of a time in motion, are also explored in Freyre's Mansions. Setting out to identify the primordial injunctions and movements that eventually led to the construction of a new society, Freyre argues that it was from the "sugar mills [engenhos], eager to free themselves from the 'directed economy' [economia dirigida] of the Captain Generals of His Majesty, that the 'first desires [primeiros anceios] for independence and democracy' were unleashed in Brazil" (Freyre, I936: 84). Mansions once again converges with Roots (Holanda, I936: 74-75) through its depiction of the "mining industry" [industria das minas] as an important stimulus for changes in the living conditions in the colony, leading to a "more direct intervention of the Crown in Brazil's affairs" (Freyre, I936: 30). These transmutations, which would end up tilting the political structure towards emergent agents and classes, resulted in the social, political and economic repositioning of old figures, the rise of new social types and categories (Freyre, I936: 35-36) and, undoubtedly, an ever more complex and dynamic scenario.

Roots and Mansions, it is worth noting, also concur in associating these outbreaks of complexification - signals of a time in movement - with the first solid steps towards urbanization, an omen of the "collapse in the resistance [perda de resistencia] of agrarianism, once sovereign", the "decline [definhamento] of the conditions that stimulated the formation among us of a powerful rural aristocracy" (Holanda, I936: I38) and, subsequently, a "tremendous social disequilibrium" (Holanda, I936: 99). In contrast, then, with the stagnation and inertia of the past, the "growth of cities and towns [burgos]" not only testified to the cooling of the monarch's relations with the rural landowners (Freyre, I936: 46), it also created "new social distances [...] between rich and poor, whites and people of colour, the manor house and the small house" [a casa-grande e a casa pequena] (Freyre, I936: I5-I6). As unequivocal proof of the new situation, this sequence of transformations could be observed in aspects as varied as basic etiquettes of behaviour and posture, clothing, generational, racial and gender tensions, as well as the very architecture of urban buildings (Freyre, I936: 20-2 I, I I5, I62, 302-303).

This said, an analysis of Mansions and Roots also reveals a third modality or connotation of time: from a determined moment, the authors argue, Brazilian society had incorporated patterns of sociability more aligned with modernity in the wake of an increasingly vertiginous dynamics.

\section{ACCELERATION: TOWARDS MODERNITY ${ }^{10}$}

In the final chapter of Roots, Sérgio Buarque (1936: I36) refers to the "great Brazilian revolution" as "a protracted process" [um processo demorado], but definitive in its developments and implications: extending from at least "the transmission of the Portuguese royal family" to the events of I889, this "secure 
and concerted" revolution (Holanda, I936: I35-136) led Brazil in other directions, thereafter without "the traditional brakes [freios tradicionaes] against the advent of a new state of affairs [um novo estado de coisas]" (Holanda, I936: I36). In contemplating those "three-quarters of a century", Sérgio Buarque takes Abolition "as perhaps the most decisive moment of all our national development" (Holanda, I936: I36), "the watershed [marco divisório] between two eras", when "Brazilian life shifts clearly from one pole to another", with the complete imposition of "urbanocracy" (Holanda, I936: 43). Ultimately, we are faced with a "new system with its base no longer in the rural domains but in the urban centres" (Holanda, I936: I37). ${ }^{\text {II }}$ Though acknowledging its incompleteness - hence the certainty that "for a long time" [durante largo tempo] Brazil would continue to feel "the last resonances" of the status quo ante - Sérgio Buarque qualifies such changes as a veritable "cataclysm", given its effect of "annihilating the Iberian roots of our culture" in favour of the "inauguration of a new style" (Holanda, I936: I37). Put otherwise, the timid movement of the past, which had merely aroused colonial life from its prolonged lethargy, finally achieved a force, speed and range without parallel in the course of the nineteenth century: not only did the pace of transformations quicken dramatically, the latter acquired a fairly clear direction - towards modern sociability.

Mansions is equally emphatic concerning the significance of this metamorphosis. Freyre remarks on "a period of profound differentiation," a "terrible period of transition", during which it was possible to observe with increasing intensity "less patriarchalism [...] and more individualism" (Freyre, I936: 54). The new signs of the era left no doubt about what was becoming established with implacable force: around I8Io, the writer observes, "the Gazeta do Rio de Janeiro announced coaches arriving from London; English carriages with their harnesses; a 'very rapid' [muito ligeira] four-wheel English coach" (Freyre, I936: 294) - unavoidable evidence of the "prestige of the wheel, the machine, the horse, their triumph over the palanquin, the arm of the slave and the slowmoving ox" (Freyre, I936: 294). Rather than mere borrowings with little connection to the national reality, these new habits and "[n]ew life-styles" began to find solid footing in the "Europeanization of labour and to a certain point of commerce", imposed "through the industrialization of Brazilian life" (Freyre, I936: 300). By the end of these alterations, a "New pace [rythmo] of life" had come to prevail (Freyre, I936: 300).

Here Mansions notably converges once again with Roots in stressing the social and political implications of these frenetic changes, crowned by the "greater prestige of the cities" (Freyre, I936: 37) - a prestige accompanied by improvements in urban services, the modernization of the "technique of transport" (Freyre, I936: 54) and, of course, political centralization away from the "predominance of family" and towards the state apparatus (Freyre, I936: I07-I08). Just like Sérgio Buarque (Holanda, I936: I39-I40) - for whom "continuous, pro- 
gressive, overwhelming urbanization" had overthrown the "powerful rural mainstay [esteio]" of the past (Holanda, I936: I4I) - Freyre also emphasizes the growing relevance assumed by new social figures: "graduates [bachareis] and physicians, some children of mechanics or peddlers [mascates] with black and mulata women" (Freyre, I936: 37-38) who emerged in the urban setting, assisted by the "greater [...] opportunities for social ascension" (Freyre, I936: I60). With the completion of these processes, "the European technician ended up triumphing. Until the mulato learnt how to drive trains, manufacture glass, make pasta and noodles [aletria]" (Freyre, I936: 30I). At a certain point, nothing seemed able to resist such ardour, most clearly symbolized by the desolate supremacy of the rhythm of the clocks (Freyre, I936: 300).

The reflections of Roots and Mansions concerning Brazil's adherence to these new ethical-moral and aesthetic-expressive references, these new behavioural patterns, these institutional structures and legal ordinations, and lastly these mental frameworks and worldviews - in general terms, societal patterns that had also become crystallized and disseminated in Europe and North America systematically over the nineteenth century - note the country's adaptation to a certain temporal configuration typically associated with modern experience: overwhelmed by a time that accelerated at an ever growing pace, Brazilian society seemed to them increasingly compelled to adjust to the cadence and march of modernity. Even so, considering the nuances and modulations of these images, this alignment did not seem to have proceeded with the same pace and harmony encountered in these paradigmatic scenarios. As I wish to underscore, the allusions to the time that pervade Mansions and Roots also contributed to project onto Brazil images of a disjunctive and discontinuous experience vis-à-vis the modern setting.

\section{COMPOSITE TIME AND SOCIABILITY IN MODERN BRAZIL}

Going by the depictions contained in Roots and Mansions, while the changes experienced over the nineteenth century had brought the country closer to prototypical modern contexts (Freyre, I936: 77; Holanda, I936: I40), these impulses towards synchronization did not produce results entirely harmonious, definitive or fully aligned with the parameters of modernity. Indeed, they argue, there was no lack of evidence and accounts to confirm the sensation of a disjuncture (Freyre, I936: 279-280) - as Brazil's “administrative structure" revealed, according to Sérgio Buarque, forced to resort to "elements from the same contingent [massa] as the former rural landowners", that is, individuals "linked to the old domestic system, still in full vigour [viço], not only in the cities but on the farm estates too" (Holanda, I936: 99).

Nevertheless, it would be misleading to suggest that the authors considered such "mismatches" to derive primarily from the delay (atraso) of Brazilian society and/or merely from its late adherence to the modern order. Were 
that the case, it would suffice for time to pass for the "hiatuses" to be shortened and, at a certain point, become extinguished entirely. Their diagnosis is other, however, just as the expectations concerning the repercussions of the country's modernization are diverse: rather than an efficient cause of Brazil's "dealignments", the first editions of Roots and Mansions indicate that the country's "delay" and "late entry" themselves constituted effects and symptoms of deeper specificities, which had long inclined Brazilian society to assume a unique temporal configuration. It is these specificities to which the works turn to explain its sui generis modernization. Ultimately, they were held responsible for the fact that, in the Brazilian case, the transformations experienced in the nineteenth century, rather than placing the country once and for all on the progressive march of modernity, had led to unequivocal asynchronies - that is, a society fractured by internal mismatches, marked by all kinds of dealignments and, no less important, out of synch with the pace of the paradigmatic modern scenarios. In sum, as the critical literature itself indicates, the formulations of Mansions and Roots fix on the existence of a perennial core of identity, a primary source of the most crucial predicates of Brazilian society, resistant to the uniformizing pressures of modernization (Burke \& Pallares-Burke, 2009: 21 3; Souza, 2000: I67; Waizbort, 20I I: 49-50).

Given the restricted focus of this article, what matters to me here, on one hand, is to discern the temporal sharing of these ideas: exploring the propositions of the two essays, unlike the temporality more frequently associated with modernity - homogenous, abstract, linear, progressive and oriented towards the future (Anderson, I99I; Giddens, I99I; Gumbrecht, 2015; Habermas, I990) - in the Brazilian society that took shape from the nineteenth century both the present time and its possible futures continued to be saturated with tangible (i.e. non-abstract) elements bound to a singular past, feeding on it (and, to a large extent, being encircled by it) during its leaps towards the modern order (Bastos, 2003: I35, I46-I52; Cavalcante, 2008: I5I; Feldman, 2013: I2I; Lage, 2016: I 26, 354-355; Ferreira, I996; Pesavento, 2005: 60; Vecchi, 2005: 167I68; Waizbort, 20I I: 49-50; Wegner, 2000: 5I). Moreover, rather than provisional or circumstantial, this composite temporal configuration, "dense and heterogenous" (Chatterjee, 2008: 63), with its disjunctive effects on reality, would prove to be as fundamental as distinctive of this societal experience. In sum, we are faced with "a peculiar sense of time" (Lage, 20I6: I27): a "protended temporal structure" (Nicodemo, 20I4: 48), marked by the "permanence of one time within the other" (Vecchi, 2005: I74) or, put otherwise, by the "accumulation of times" that "anticipate" but also "hinder each and every process of transformation" (Pesavento, 2005: 69).

Having said this, it is also important to stress that the allusions of Mansions and Roots to this special time (thick, composite and heterogenous) are found intertwined with images of a pattern of sociability in Brazil equally divergent 
from the kind commonly attributed to the societies prototypical of modernity - a pattern of sociability characterized by the permeability between social life and the dynamic of natural world, rooted in subjectivities decentred and out of step from modern imperatives and institutions, marked by the overlapping of private codes of conviviality and public rules of sociability, configured by the interpenetration of diverse social spheres and domains, and, finally, by the marked influence of non-secularized conceptions of the world in public and private spaces (Tavolaro, 20I4: 642-644). Filled with resounding temporal connotations, these images converge to intensify the sense of Brazilian society being out of phase, confirming its marginal status in the modern setting and, as can be inferred, feeding the impression that modernization in the country followed a route as torturous (non-linear) as it was filled with vacillations and retreats (non-progressive).

In my view, these depictions do not entirely delimit the perceptual horizons of the essays, however. In their attempts to discern what was distinctive in Brazil, both Roots and Mansions do, of course, end up accepting these same parameters disseminated in the sociological imaginary - hence the recurrent correlations with contexts that occupy a "model position", situated at the "forefront of social time" (Feldman, 2009: I I I-I I2). Nevertheless, insofar as one extends and deepens the implications of the relational/transactional dimension of the works, their formulations concerning the Brazilian experience indicate a certain potential to diversify and amplify the repertoire of conceptions concerning modernity and its temporality(ies).

\section{MANSIONS AND ROOTS: CONTRIBUTIONS TO THE SOCIOLOGICAL IMAGINATION OF MODERNITY}

Prominent in the sociological imagination is the idea that the advent of the modern era constituted a rupture in time, the dawn of an era without precedents, broken loose from everything that had preceded it and oriented predominantly towards the future (Gumbrecht, 20I5: I4-I5; Habermas, I990: I6-I7; Koselleck, 2006: 294). At the end of the increasingly rapid social transformations and processes (Koselleck, 2006: 282; Rosa, 20I3: 7I-80) and ensnared in the establishment of new societal parameters, "the standardization of temporal reference" (Zerubavel, I982: 2) had expanded sufficiently to allow for "different people to measure the passage of time in an identical manner", that is, "to date any past, present or future instant in a common fashion" (Zerubavel, I982: 3). Emancipated from particular spatial connections (Giddens, I99I: 25-29; Rosa, 20I3: 28-29), this "homogenous, empty" temporality, "measured by the clock and by the calendar" (Anderson, I99I: 24), had contributed to the "global dissemination" of institutions that, though gestated in the West, were projected to the four corners of the planet (Giddens, I99I: 57). Abstract and uniform, progressive and linear, this temporal configuration was seen to express - in the same propor- 
tion in which it promoted - a unique modality of sociability: divorced from the imperatives and movements of the natural world; anchored in individuals endowed with centred subjectivities; marked by the radical separation between public and private domains; by the complete differentiation and specialization of diverse social spheres and arenas; and, finally by cognitive and ethical-moral rationalization (Tavolaro, 2008: 275; 2017: I 20-I 22; Rosa, 2013: 58). A product of historical transformations (social, political, cultural, epistemological, economic and so on) normally taken to be intrinsic to a determined region of Europe, such parameters and references later spread out to other parts of the world. Nonetheless, in "delayed" modern contexts, these societal patterns (including their schemas, categories and temporal-spatial experiences) would end up acquiring their own modulations and formats, consistent with their idiosyncrasies and particular trajectories.

By way of conclusion, in dialogue with contemporary reflections (Chakrabarty, 2000; Chatterjee, 2008; Gumbrecht, 20I5; Hall, 20I I; Harootunian, 2007) and with the critical literature on the authors (Avelino Filho, I990; Feldman, 2009; Lage, 20I6; Rocha, 2008; Villas Bôas, 2003), my interest resides in evaluating whether Mansions and Roots possess elements that, on one hand, enable an alternative to the substantialism and internalism subjacent to this sociological imaginary and, on the other, allow us to amplify the array of notions and perceptions relating to modernity. It is no novelty that, with considerable regularity, experiences like the Brazilian case tend to be framed as configurations shaped in the course of particular societal itineraries, away from or on the margin of the so-called central countries. This would explain precisely one of the sources of the country's divergences from the modern pace of life and its characteristic pattern of sociability. While this same diagnosis is not entirely alien to Roots and Mansions, the relational/transactional dimension of their depictions of the country encourages a different approach. Certainly, the references of the works to Brazil's supposed specificities, not infrequently underlined in contrast to "prototypical" contexts of modernity, tend to reinforce perceptions of the former as a deviant experience in the contemporary scenario. Even so, we cannot underestimate the innumerable moments in which these same essays allude to the country's engagement, from far back, in a vast "system of international relations" (Freyre, I936: 283); neither can we ignore the recurrent connection between "our forms of life, our institutions and our worldview" and Brazil's ties to "distant countries" and places (Holanda, I936: 3). In these cases, moving away from the comparative analytic emphasis in favour of the exploration of "connected histories", ${ }^{12}$ both works invite us to examine the country's formation and modernization (as well as the experiences of other societies) in light of the multiple entanglements (cultural, political, economic, epistemological and so on) established between diverse regions of the planet since the dawn of modernity. 
In my view, this other analytic perspective also inscribed in Mansions and Roots contains theoretical-interpretative suggestions that may be projected beyond the preferred referents of the works themselves. On this point, the insights and analyses of Rocha (2008), Feldman (2009) and Lage (2016) prove fertile. As I wish to emphasize, the transactional/relational dimension in which "Brazil [...] is enunciated as a country entangled with world politics" (Feldman, 2009: Io) through "its different encounters with modernity" (Lage, 2016: I 23) the opposite, therefore, to a certain "self-referential, essentialist nationalism", which pretends that the country is the "root, the origin of itself" (Rocha, 2008: 265) - enables us to pursue an alternative intellectual path to the modern experience, resistant to the "internalist" and "substantialist" traps mentioned above. Taking another step in this direction, we are persuaded to conceive modernity itself, from its most remote origins, beyond "a particular European trajectory" (Subrahmanyam, I997: 737) - that is, attentive to its expressive historical density and its countless "entanglements" (Therborn, 2003: 295), exchanges and transits (cultural, political, economic, technological, epistemological, institutional, ethical-moral and aesthetic). ${ }^{\mathrm{I}}$ Taking into account the power differentials imbued in these processes, such a step implies reframing modern experience as "a more-or-less global shift, with many different sources and roots, and - inevitably - many different forms and meanings" (Subrahmanyam, I997: 737). This even allows us to cast doubt on the existence of modern patterns of sociability essential to each particular context and/or each specific position, and crystallized in the wake of supposedly unique historical trajectories. $^{\text {I4 }}$

A significant portion of these problems are considered by Lage (2016) in the author's exploration of the notions of the "contemporaneity of the non-contemporaneous" and "contemporaneity", the latter understood as the "the encounter of different times and spaces; of universals and particulars" (Lage, 2016: 550-565). Wielding these ideas, Lage (2016: 560) seeks to highlight the "heterogeneity of time" evoked in key essays in the "interpretation of Brazil". Discerning in these works "a wider problematization of the lines of demarcation that separate and unite inside and outside, the past, present and future" (Lage, 2016: 572), as well as the capacity to "expose a global process" (Lage, 20I6: 559), the author comes to perceive them as "potential sites of critique of modernization" (Lage, 20I6: 36) - given the fact that they question "central concepts of what is usually defined as 'modernity"” (Lage, 2016: 533). In my view, these propositions are comparable to other more or less recent elaborations in social theory that point precisely to the multiplicity and overdetermination of diverse times observed in the midst of modernity (Hall, 20II: I08-I09; Chatterjee, 2008: I07-I2 I; Gumbrecht, 20I5: I5-I6; Harootunian, 2007: 474). Following the reflections of Harootunian (2007: 474), the predominance of a "progressive", abstract and linear conception of time, usually attributed to the "industrial centres of Euro-Amer- 
ica" (Harootunian, 2007: 480), was accompanied on one hand by the "diminished awareness of the persistence of coexistent temporalities" (Harootunian, 2007: $480)$ at the very core of these contexts and, on the other hand, the exteriorization of "the image of dissonant rhythms to the periphery, where it became a sign of a rift between modernity and nonmodernity" (Harootunian, 2007: 480). Once hidden the "mixed, and often "discordant temporalities" regulating the rhythms of life" (Harootunian, 2007: 474) in its own interior, this "collision of temporalities" would soon become a stereotype of "the nonmodern" (Harootunian, 2007: 474). Nonetheless, for the author, it is very possible that the combination of "multiple temporalities" in the "historical present" (Harootunian, 2007: 486), or "the articulation of these ambiguous mixtures of modern and archaic, new and old, here and there, contemporary and nativist has always been present to remind us of the perseverance of a temporal refraction distinguished by noncontemporaneous contemporaneity" (Harootunian, 2007: 475).

As I have been arguing, this change of perspective has important implications for the analytic-descriptive range of the depictions of Brazil traced out in Roots and Mansions. As highlighted earlier, while acknowledging the particularities of each essay, their first editions converge on five aspects that would confirm the uniqueness of the pattern of sociability crystallized in Brazil (Tavolaro, 2017: I 25-I28): firstly, these depictions point to a society susceptible to the dynamics and functioning of the natural world, falling short of the technical control and domination of nature observed in paradigmatic modern contexts (Holanda, I936: 26-27, 62-63; Freyre, 1936: 252-254). Secondly, given the prevalence of the passional and impulsive in the "national character" - the source of the frequent imprudence, lack of discipline and behavioural vagaries of the average Brazilian - it also seemed to them that Brazil lacked the conditions for the overall consolidation of the figure of the individual, endowed with a centred and stable subjective life, capable of imposing his or her will on the changing circumstances of the environment and taking rational decisions (Holanda, I936: 33, 46-47, I05; Freyre, I936: 356-358). Also in contrast to prototypical modern societies, public and private Brazilian domains are said to have remained shuffled, such that codes from the domestic-family sphere and primary contacts supposedly continued to project and intrude into spaces of sociability in which, under entirely modern conditions, impersonality and universal respect of the individual's privacy should prevail (Holanda, I936: 88-89; Freyre, I936: 23, 7I). Furthermore, the processes of complexification and social differentiation observed in Brazil was taken to have attained neither a similar scope or level nor an analogous depth to the so-called central societies; hence why politics, economy, civil society, culture, along with other social spheres and domains, remained largely entangled, sometimes juxtaposed, in detriment to their relative autonomy and the fulfilment of their specific functions (Holanda, I936: 32, 4647, I00-IOI; Freyre, I936: 84-85, 202). Finally, the societal rationalization most- 
ly associated with originary/avant-garde contexts of modernity, with their normativity founded on general and abstract principles, seemed to them hesitant and superficial in Brazil, a situation confirmed by the continuing influence of magical and religious conceptions of the world at the heart of society (Holanda, I936: II-I 2, 99-I00, I05, I08; Freyre, I936: I5-I6, 7I, 365-366).

If the aforementioned relational/transactional dimension of both works can sensitize us to envisage modernity itself in light of the countless historical and societal connections in which it was always involved, there follow at least two theoretical-interpretative implications: first, the Brazilian configuration can be conceived beyond the stigma of "deviation"; and second, it can be plausibly argued that the patterns of sociability discerned in Mansions and Roots, as well as the connotations and senses of time that they employ, far from being limited to the supposed uniqueness of the country's historical itinerary, constitute alternative parameters for the sociological imagination of modernity. In sum, it becomes conceivable to affirm that in addition to their ability to capture and depict the societal repercussions of the formation and modernization of Brazil, Mansions and Roots, each in its own way, also successfully provide evidence of other aspects and facets of the modern experience itself, considered more widely - facets and aspects rendered invisible by the sociological imaginary or, in the best hypothesis, linked only to societal contexts frequently catalogued as "delayed," "marginal" or "non-paradigmatic." As a consequence, such images and depictions can be adopted among the array of conceptions and connotations that equip the sociological discourse to codify, describe and comprehend the enormous diversity of experiences that coinhabit and constitute modernity - in its "peripheries," but also in its "centres."

Received on 5/7/2018 | Revised on 8/4/2019 | Approved on 29/4/2019

Sergio B. F. Tavolaro is Associate professor in the Department of Sociology at the University of Brasília and CNPq Researcher (PQ ID). He holds a Ph.D. in Sociology from The New School for Social Research and is the author of Cidadania e modernidade no Brasil (I930-I945). 


\section{NOTES}

I This article was supported by CNPq (303342/20I5-3). I thank the anonymous reviewers for their valuable criticisms, which helped me improve my argument. I also thank David Rodgers for the translation of the article.

2 My intention here is not to reveal or bring out any substantive notion of time prior and external to Mansions and Roots as an analytic parameter for their propositions. Rather, I aim to investigate the connotations and meanings intrinsic to the essays themselves in order to identify and analyse their depictions of Brazilian society and its status within modernity.

3 TN: In Portuguese, delay is atraso, a term also signifying retardation, backwardness.

4 On this point, see the formulations of Costa Pinto (I978: 53-55) and Florestan Fernandes (2008: 60-6I). For a meticulous analysis of the centrality of this aspect in key figures of Brazilian thought, I recommend the work of Victor Lage (2016).

5 As Mustafa Emirbayer (I997: 282) contends, "the substantialist perspective [...] takes as its point of departure the notion that it is substances of various kinds (things, beings, essences) that constitute the fundamental units of all inquiry."

6 Sebastian Conrad (2016: 88) argues that: "Conventional social histories generally operate within what can be called an internalist paradigm," owing to which societies tend to be treated as "self-generating" entities. This leads to a certain propensity to taking the very predicates of these societies as the main sources of their transformations.

7 According to François Dépelteau (2013), given that for transactional sociology "A and B are interdependent", its fundamental premise is that "A does not do what it does without transacting with $B$, and vice-versa" (Dépelteau, 2013: I78, original emphasis). To the extent that all "capacities and their related actions happen always in relation to something else," the analytic emphasis must be on the actual "transactions" between the involved parties (Dépelteau, 2013: I80). 
8 All excerpts from Roots and Mansions cited in this article are translations from the first Brazilian editions of both works (1936). A special effort has been made to remain as faithful as possible to their original meanings.

9 The bibliography on this theme is profuse. As an example, see Reinhart Koselleck (2006: 294), who conceives modernity as an era "of rupture" as well as "transition" in which "acceleration" became "a basic experience of time." Again it is worth stressing that rather than constituting parameters extrinsic to the elaborations of Roots and Mansions, the terms stasis, motion and acceleration are employed here with the aim of codifying meanings and connotations inscribed in the works themselves, which in my view circumscribe and orient their images concerning the Brazilian experience, its societal connections, as well as Brazil's status under modernity. Although Pesavento (2005) focuses on Roots, I think that acceleration can also be useful to the investigation of Mansions.

Io Along with Koselleck (2006), Hartmut Rosa (2013) also argues that "the experience of modernization is an experience of acceleration" (Rosa, 20I3: 2I, original emphasis). Generally speaking, at least some of his descriptions of what he calls social acceleration help us access this third connotation of time inscribed in the depictions of Brazil found in Roots and Mansions. According to Rosa (2013: 7I-80), social acceleration comprises "three types of phenomena": "technical acceleration", "the acceleration of social change", and "the acceleration of the pace of life". It is not difficult to perceive them all implicated in the acceleration of time.

II According to Sandra Pesavento (2005: 72), for Holanda, along with the bandeirantes, the "process of industrialization" and urbanization "represent, in time, an acceleration and a promise of a future" (my emphasis).

I 2 Here I refer to the sense of the expression used by Subrahmanyam (1997: 744-745) and Gruzinski (2003: 323) - although the latter judged Sérgio Buarque's work on Portuguese colonization to be indebted to a comparative perspective (Gruzinski, 2003: 322).

I3 In this case, it becomes essential to "re-establish the international and intercontinental connections that the national historiographies and cultural histories discon- 
nected or concealed, sealing off their respective frontiers" (Gruzinski, 2003: 323).

I4 Ultimately, as the proposals of Hall (20II: IO8-IIO) and Chatterjee (2008: 57-88) seem to indicate, it is also possible to question the strict distinction of a linear, abstract, progressive and homogenous time exclusive to the "Centre" in comparison to a hybrid, heterogenous, sinuous and thick time characteristic of the "Periphery."

\section{BIBLIOGRAPHY}

Anderson, Benedict. (I99I). Imagined communities. London: Verso.

Araújo, Ricardo. (I994). Guerra e paz: Casa-grande \& Senzala e a obra de Gilberto Freyre nos anos 30. Rio de Janeiro: Ed. 34. Avelino Filho, George. (I990). Cordialidade e civilidade em Raízes do Brasil. Revista Brasileira de Ciências Sociais, 5/I2, p. 5-I4. Bastos, Elide. (2013). A construção do debate sociológico no Brasil. Ideias, I, p. 287-300.

Bastos, Elide. (2008). Raízes do Brasil - Sobrados e Mucambos: um diálogo. In: Monteiro, Pedro \& Eugênio, João (eds). Sérgio Buarque de Holanda: Perspectivas. Campinas/Rio de Janeiro: Ed. Unicamp/Ed. Uerj, p. 227-244.

Bastos, Elide. (2006). As criaturas de Prometeu. São Paulo: Global. Bastos, Elide. (2003). Gilberto Freyre e o pensamento hispânico: entre Dom Quixote e Alonso El Bueno. Bauru: Edusc.

Burke, Peter. (2013). Tropicalização, tropicalismo, tropicologia: a contribuição de Gilberto Freyre. In: Mota, Roberto \& Fernandes, Marcionila (eds.). Gilberto Freyre: região, tradição, trópico e outras aproximações. Rio de Janeiro: Fundação Miguel de Cervantes, p. I98-2I2.

Burke, Peter \& Pallares-Burke, Maria L. (2009). Repensando os trópicos: um retrato intelectual de Gilberto Freyre. São Paulo: Ed. Unesp.

Candido, Antonio. (2008). A visão política de Sérgio Buarque de Holanda. In: Monteiro, Pedro \& Eugênio, João (eds). Sérgio Buarque de Holanda: Perspectivas. Campinas/Rio de Janeiro: Ed. Unicamp/Ed. Uerj, p. 29-36. 
Cavalcante, Berenice. (2008). História e modernismo: herança cultural e civilização nos trópicos. In: Monteiro, Pedro \& Eugênio, João (eds.). Sérgio Buarque de Holanda: Perspectivas. Campinas/Rio de Janeiro: Ed. Unicamp/Ed. Uerj, p.I37-I54.

Chakrabarty, Dipesh. (2000). Provincializing Europe. Princeton: Princeton University Press.

Chatterjee, Partha. (2008). La nación en tiempo heterogéneo. Buenos Aires: Siglo Veintiuno.

Conrad, Sebastian. (2016). What is global history? Princeton: Princeton University Press.

Costa Pinto, Luiz A. (1978). Desenvolvimento econômico e transição social. Rio de Janeiro: Civilização Brasileira.

Crespo, Regina. (2003). Gilberto Freyre e suas relações com o universo cultural hispânico. In: Kosminsky, Ethel; Lépine, Claude \& Peixoto, Fernanda (eds.). Gilberto Freyre em quatro tempos. Bauru/São Paulo: Edusc/Ed. Unesp, p. I8I-204.

Dépelteau, François. (2013). What is the direction of the "relational turn"? In: Powell, Christopher \& Dépelteau, François (eds.). Conceptualizing relational sociology. New York: Palgrave Macmillan, p. I63-185.

Emirbayer, Mustafa. (I997). Manifesto for a relational sociology. American Journal of Sociology, I03/2, p. 28I-3I7.

Eugênio, João. (2008). Um horizonte de autenticidade Sérgio Buarque de Holanda: monarquista, modernista, romântico (I920-I935). In: Monteiro, Pedro \& Eugênio, João (eds.). Sérgio Buarque de Holanda: Perspectivas. Campinas/ Rio de Janeiro: Ed. Unicamp/Ed. Uerj, p. 425-459.

Feldman, Luiz. (2013). Um clássico por amadurecimento: Raízes do Brasil. Revista Brasileira de Ciências Sociais, 28/82, p. II9-I40.

Feldman, Luiz. (2009). O Brasil no mundo e vice-versa: Estado em Casa-grande \& senzala, Sobrados e mucambos $e$ Raízes do Brasil. Dissertação de Mestrado. IRI/Pontifícia Universidade Católica do Rio de Janeiro.

Fernandes, Florestan. (2008). Sociedade de classes e subdesenvolvimento. São Paulo: Global Editora.

Ferreira, Gabriela. (I996). A formação nacional em Buarque, Freyre e Vianna. Lua Nova, 37, p. 229-247. 
Freyre, Gilberto. (1936). Sobrados e mucambos: decadencia do patriarchado rural no Brasil. São Paulo: Companhia Editora Nacional.

Giddens, Anthony. (I99I). As consequências da modernidade. São Paulo: Ed. Unesp.

Gumbrecht, Hans. (20I5). Nosso amplo presente. São Paulo: Ed. Unesp.

Gruzinski, Serge. (2003). O historiador, o macaco e a centaura: a "história cultural" no novo milênio. Estudos Avançados, I7/49, p. 32I-342.

Habermas, Jürgen. (I990). O discurso filosófico da modernidade. Lisboa: Dom Quixote.

Hall, Stuart. (20I I). Da diáspora. Belo Horizonte: Ed. UFMG. Harootunian, Harry. (2007). Remembering the historical present. Critical Inquiry, 33/3, p. 47I-494.

Holanda, Sérgio Buarque de. (1936). Raízes do Brasil. Rio de Janeiro: Livraria José Olympio Editora.

Koselleck, Reinhart. (2006). Futuro passado: contribuição à semântica dos tempos históricos. Rio de Janeiro: Contraponto/Ed. PUC-Rio.

Lage, Victor. (2016). Interpretations of Brazil, contemporary (de)formations. Tese de Doutorado. IRI/Pontifícia Universidade Católica do Rio de Janeiro.

Larreta, Enrique \& Giucci, Guillermo. (2007). Gilberto Freyre: uma biografia cultural: a formação de um intelectual brasileiro: 1900-1936. Rio de Janeiro: Civilização Brasileira.

Mata, Sérgio da. (2016). Tentativas de desmitologia: a revolução conservadora em Raízes do Brasil. Revista Brasileira de História, 36/33, p. 63-87.

Melo, Alfredo. (20I6). Mudanças em ritmo próprio. In: Holanda, Sérgio Buarque de. Raízes do Brasil - Edição crítica. São Paulo: Companhia das Letras, p. 449-455.

Monteiro, Pedro. (20I5). Raízes rurais da família brasileira: Sérgio Buarque de Holanda e Gilberto Freyre. In: Monteiro, Pedro. Signo e desterro: Sérgio Buarque de Holanda e a imaginação do Brasil. São Paulo: Hucitec, p. 54-77.

Motta, Roberto. (2013). Tempo, desenvolvimento e (in) correção histórica: a propósito da lusotropicologia de Gil- 
berto Freyre. In: Motta, Roberto \& Fernandes, Marcionila (eds.). Gilberto Freyre: região, tradição, trópico e outras aproximações. Rio de Janeiro: Fundação Miguel de Cervantes, p. 213-242.

Nicodemo, Thiago. (20I4). Os planos de historicidade na interpretação do Brasil de Sérgio Buarque de Holanda. História da Historiografia, I4, p. 44-6I.

Pesavento, Sandra. (2005). Cartografias do tempo: palimpsestos na escrita da história. In: Pesavento, Sandra (org.). Um historiador nas froneiras: o Brasil de Sérgio Buarque de Holanda. Belo Horizonte: Ed. UFMG, p. I7-79.

Rocha, João. (20I2). Raízes do Brasil: Biografia de um livroproblema. In: Marras, Stelio (org.). Atualidade de Sérgio Buarque de Holanda. São Paulo: Edusp/IEB, p. 19-39.

Rocha, João. (2008). O exílio como eixo: bem-sucedidos e desterrados - ou por uma edição crítica de Raízes do Brasil. In: Monteiro, Pedro \& Eugênio, João (eds.). Sérgio Buarque de Holanda: Perspectivas. Campinas/Rio de Janeiro: Ed. Unicamp/Ed. Uerj, p. 245-275.

Rosa, Harmut. (2013). Social acceleration: a new theory of modernity. New York: Columbia University Press.

Souza, Jessé. (2000). A modernização seletiva. Brasília: Ed. UnB.

Subrahmanyam, Sanjay. (1997). Connected histories: notes towards a reconfiguration of early modern Eurasia. Modern Asian Studies, 31/3, p. 735-762.

Tavolaro, Sergio B. F. (2017). Retratos não modelares da modernidade: hegemonia e contra-hegemonia no pensamento brasileiro. Civitas - Revista de Ciências Sociais, I7/3, p. II5-I4I. Tavolaro, Sergio B. F. (2014). A tese da singularidade brasileira revisitada: desafios teóricos contemporâneos. Dados - Revista de Ciências Sociais, 57/3, p. 633-673.

Tavolaro, Sergio B. F. (2008). "À sombra do mato virgem ...": natureza e modernidade em uma abordagem sociológica brasileira. Ambiente \& Sociedade, I I/2, p. 273-287.

Therborn, Göran. (2003). Entangled modernities. European Journal of Social Theory, 6/3, p. 293-305.

Vecchi, Roberto. (2005). Atlas intersticial do tempo do fim: 'Nossa revolução'. In: Pesavento, Sandra (org.). Um histo- 
riador nas froneiras: o Brasil de Sérgio Buarque de Holanda. Belo Horizonte: Ed. UFMG, p. I6I-I93.

Villas Bôas, Glaucia. (2003). Casa grande e terra grande, sertões e senzala: a sedução das origens. In: Kosminsky, Ethel; Lépine, Claude \& Peixoto, Fernanda (eds.). Gilberto Freyre em quatro tempos. Bauru/São Paulo: Edusc/Ed. Unesp, p. II5-I34.

Waizbort, Leopoldo. (20I6). Raízes do Brasil: inércia e transformação lenta. In: Holanda, Sérgio Buarque de. Raízes do Brasil - Edição crítica. São Paulo: Companhia das Letras, p. 465-470.

Waizbort, Leopoldo. (20II). O mal-entendido da democracia: Sérgio Buarque de Holanda, Raízes do Brasil, I936. Revista Brasileira de Ciências Sociais, 26/76, p. 39-62.

Wegner, Robert. (2000). A conquista do oeste: a fronteira na obra de Sérgio Buarque de Holanda. Belo Horizonte: Ed. UFMG. Zerubavel, Eviatar. (I982). The standardization of time: A sociohistorical perspective. American Journal of Sociology, 88/I, p. I-23. 


\section{ESTASE, CINESIA E ACELERAÇÃO: SENTIDOS E ACEPÇÕES DO TEMPO EM SOBRADOS E RAÍZES (1936) \\ Resumo}

O artigo investiga as acepções da categoria tempo que participam dos horizontes de cognição das edições princeps (I936) de Raízes do Brasil e Sobrados e Mucambos. Ao retratar a experiência brasileira como portadora de uma configuração temporal distinta daquela identificada em sociedades tomadas por prototípicas da modernidade, essas obras tendem a caracterizar a modernização no país em dissonância com as referências institucionais, culturais, éticomorais, epistemológicas e estéticas comumente vinculadas àqueles contextos. Isso posto, conforme quer-se aqui examinar, empenhados em explanar uma configuração societária que se lhes afigurava antiparadigmática em vários de seus traços, esses mesmos ensaios logram lançar pistas valiosas para uma apreciação crítica de certo viés "substancialista" e "internalista" que, não raro, orienta a imaginação sociológica acerca da modernidade e de sua temporalidade.

\section{STASIS, MOTION AND ACCELERATION: THE SENSES AND CONNOTATIONS OF TIME IN ROOTS OF BRAZIL AND THE MANSIONS AND THE SHANTIES (1936)}

\section{Abstract}

This article investigates the senses and connotations of "time" that work to define the cognitive horizons of the first editions (1936) of Roots of Brazil and The mansions and the shanties. By ascribing to Brazilian society a temporal configuration distinct from those attributed to so-called central modern societies, both essays tend to depict Brazil's modernization as a dissonant case in terms of the institutional, cultural, moral-ethical, epistemological and aesthetic patterns commonly associated with modernity. At the same time, the article also seeks to demonstrate that these very same works - striving to explain a societal configuration that appeared to them anti-paradigmatic in many of its features - offer valuable clues for a critical assessment of the "substantialist" and "internalist" biases that frequently orient the sociological imagination concerning modernity and its temporality.

\section{Palavras-chave}

Sobrados e mucambos; Raízes do Brasil; pensamento brasileiro; modernidade no Brasil; teoria sociológica.

\section{Keywords}

The mansions and the shanties; Roots of Brazil; Brazilian sociology; modernity in Brazil; sociological theory. 